DOI: 10.32844/2222-5374-2020-103-1.51

УДК: 349.22

Іншин М. I.,

доктор юридичних наук, професор,

академік НАПрН України,

завідувач кафедри трудового права

та права соціального забезпечення,

Київський національний університет

імені Тараса Шевченка

\title{
ЗАБЕЗПЕЧЕННЯ ТРУДОВИХ ПРАВ СУДДІВ ЯК ПЕРЕДУМОВА ЇХ СОЦІАЛЬНОЇ БЕЗПЕКИ
}

В статті формується актуальна наукова думка щодо впливу забезпечення трудових прав суддів в Украӥні на рівень їх соціальної безпеки. Встановлено, що рівень соціальної безпеки суддів залежить від якості забезпечення їх трудових прав, адже такі права: існують задля сталого розвитку людини (задоволення потреб у соціальних благах, що продукуються в сфері праці) та унеможливлення виникнення ситуацій, за яких працівник зазнає приниження його людської гідності, звуження його свободи, а також інших людських прав; регламентуються загальними та спеціальними нормами, що враховують загальні для всіх працівників і особливі для суддів соціальні ризики, з метою мінімізацію негативного впливу яких державою й гарантуються відповідні права; здійснюються у відповідності до принципу законності, знижуючи рівень невизначеності як процесу реалізації суддею цих прав, так і процесу забезпечення $і$ захисту цих прав; забезпечуються та захищаються за рахунок Державного бюджету України, будучи гарантованими державою (на національному рівні) та міжнародними урядовими організаціями (на міжнародному рівні); захищаються в межах окремих загальних форм захисту трудових прав суддів, а також у рамках спеціально створених для суддів способів захисту вказаних прав; окреслюють рівень цивілізованості суспільства. Доводиться, що особливості трудових прав суддів й їх вплив на соціальну безпеку суддів, вимагають від держави створення сприятливих умов для їх забезпечення. У випадках, коли державою ігнорується такий обов'язок $і$ трудові права судді в достатній мірі не забезпечуються, відповідна держава не може вважатись соціальною, правовою та демократичною. Відсутність гарантій реалізації трудових прав суддів, що сьогодні відбувається на Україні, негативно впливає на забезпечення незалежності судів та належне здійснення правосуддя в державі.

Ключові слова: соціальна безпека, суддя, судово-правова реформа, трудові права, трудові правовідносини.

В статье формируется актуальная научная мысль о влиянии обеспечения трудовых прав судей в Украине на уровень их социальной 
безопасности. Определено, что уровень социальной безопасности судей зависит от качества обеспечения их трудовых прав, поскольку такие права: существуют для устойчивого развития человека (удовлетворение потребностей в социальных благах, продуцируемых в сфере труда) и предотвращения возникновения ситуаций, при которых работник испытывает унижение его человеческого достоинства, сужения его свободы, а также других прав человека; регламентируются общими и специальными нормами, учитывают общие для всех работников и особые для судей социальные риски, с целью минимизации негативного влияния которых государством и гарантируются соответствующие права; осуществляются в соответствии с принципом законности, снижая уровень неопределенности как процесса реализации судьей данных прав, так и процесса обеспечения и защиты этих прав; обеспечиваются и защищаются за счет Государственного бюджета Украины, будучи гарантированным государством (на национальном уровне) и международными правительственными организациями (на международном уровне); защищаются в пределах отдельных общих форм защиты трудовых прав судей, а также в рамках специально созданных для судей способов защиты указанных прав; определяют уровень цивилизованности общества. Доказывается, что особенности трудовых прав судей и их влияние на социальную безопасность судей, требуют от государства создания благоприятных условий для их обеспечения. В случаях, когда государством игнорируется такая обязанность и трудовые права судьи в достаточной мере не обеспечиваются, соответствующее государство не может считаться социальным, правовым и демократическим. Отсутствие гарантий реализации трудовых прав суддей, что сейчас происходит на Украине, негативно влияет на обеспечение независимости судов и надлежащее отправление правосудия в стране.

Ключевыеслова:социальнаябезопасность, социальныеправа, судебноправовая реформа, судья, трудовые права, трудовые правоотношения.

Актуальність теми. На сьогоднішній день судді в Україні $\epsilon$ працівниками, адміністративна та процесуальна трудова діяльність котрих становить підгрунтя, на якому вибудовується та існує правова, соціальна та демократична держава. Вказане пояснюється тим, що:

1) «усі суспільні блага створюються працею» [1, с. 112] і з цього правила не $\epsilon$ виключенням також процес створення правової держави, що $€$ особливим благом, в якому може набути реальну цінність найвища соціальна цінність - людина, її життя та здоров'я. При цьому правова держава створюється та існує за допомогою функціонування судової влади, що в будь-якій правовій державі $€$ «запобіжником непорушності панування права в суспільстві й поглиблення панування права у відповідній державі шляхом захисту в межах реалізації правосуддя: держави від держави; держави від суспільства, окремих груп людей і від людини; людини від держави; людини від суспільства та груп людей; людини від іншої людини» [2, с. 141];

2) суддя, як працівник, котрий має статус професійного публічного службовця, що продукує особливе «благо»- обумовлює безпосередню об'єктивацію судової влади: а) набуває такого статусу «на підставі та з ура- 
хуванням загального правового статусу громадянина, правових відносин, в яких він бере участь» [3, с. 49] (при цьому маються на увазі саме службово-трудові правовідносини, які регулюються нормами законодавства про працю та про судоустрій і статус суддів, з урахуванням міжнародно-правових стандартів роботи суддів); б) реалізуючи такий статус виконує «роботу судді», котра, як зазначає вітчизняна учена та суддя О. В. Карпушова, постає в якості «нормативно врегульованого трудового виду діяльності судді як суб'єкта трудового права із спеціальним статусом, спрямованого, з одного боку, на здійснення правосуддя, а з іншого - на реалізацію опосередкованих завдань, обумовлених специфікою судової влади та особливістю службово-трудових відносин, в яких суддя перебуває» [4, с. 19]. Таким чином, у процесі своєї трудової діяльності суддя формує та скріплює фундамент правової держави. Очевидна соціальна особливість роботи судді виявляється у тому, що вона: а) є «індикатором», «якісні характеристики якого дозволяють державу, в якій виконує роботу суддя, віднести до групи правових держав» [4, с. 19]; б) «культивує справедливість і панування права у суспільстві» [4, с. 20]; в) «наближує владу (усю систему суб'єктів публічної адміністрації та суб'єктів публічної влади загалом) до суспільства крізь призму правозастосування» [4, с. 26]; г) «сприяє якісному функціонуванню суду та судової системи, підвищує авторитет державних органів в очах громадян» [4, с. 26].

Надзвичайне соціально-правове значення трудової діяльності (роботи) судді (особливо в площині процесуальної діяльності), разом 3 існуючими гарантіями незалежності суду та самостійної роботи суддів, вказує на те, що суддя може належним чином виконувати свої службовотрудові обов'язки лише тоді, коли він матиме належний рівень соціальної безпеки, котрий відтак постає в якості окремої гарантії незалежності системи правосуддя. У цьому контексті виникає необхідність в дослідженні цього аспекту у площині трудового і соціального права, а саме в аспекті забезпечення трудових і соціальних прав суддів, що $є$ основою належного обсягу соціальної безпеки вказаних працівників. Загострюють необхідність дослідження вказаного питання: 1) загальне зниження рівня соціальної безпеки працівників в Україні, а також стрімке погіршення забезпечення стандартів гідної праці суддів; 2) перспектива здійснення чергової судовоправової реформи, в якій (з огляду на наявні проекти дій щодо такої реформи) законодавцем вкотре ігнорується потреба створення комплексу належних умов для повноцінного забезпечення трудових і соціальних прав суддів.

Аналіз наукової літератури та невирішені раніше питання. Забезпечення трудових і соціальних прав працівників, а також вплив такого процесу на рівень соціальної безпеки працівника вже у тій чи іншій мірі були досліджені Л. П. Амелічевою, М. І. Ануфрієвим, Е. В. Бабенком, С. В. Вишновецькою, М. В. Голіковою, М. А. Дідиченко, О. В. Епель, Г. А. Зубом, О. В. Карпушовою, В. Л. Костюком, Л. В. Котовою, Б. Б. Курбановим, П. М. Мартиновим, М. В. Панченком, В. С. Пряниковим, I. C. Сахарук, O. А. Старокожевим, Р. В. Татаріновим, Р. I. Шабановим, Т. В. Штих, О. В. Яснолобовим та іншими вітчизняними науковцями. Разом із тим, слід констатувати, що на сьогоднішній день актуальною є потреба 
у подальшому аналізі впливу забезпечення трудових прав суддів на рівень їх соціальної безпеки, враховуючи останні зміни чинного законодавства та актуальні напрацювання вітчизняних юристів-трудовиків.

Відтак, метою цієї наукової статті $\epsilon$ формування актуальної наукової думки щодо впливу забезпечення трудових і соціальних прав суддів в Україні на рівень соціальної безпеки суддів. Окреслена мета досягатиметься шляхом виконання таких завдань: 1) визначити особливі риси трудових прав суддів; 2) проаналізувати зв'язок забезпечення цих прав із рівнем формування належної соціальної безпеки вказаних працівників; 3) виокремити та проаналізувати особливі ознаки соціальних прав суддів у взаємозв'язку із впливом процесу забезпечення цих прав на рівень соціальної безпеки суддів; 4) узагальнити отримані результати дослідження.

Виклад основного матеріалу дослідження. Трудові права працівників вітчизняними науковцями переважно інтерпретуються в якості специфічних можливостей людини (котра має належний обсяг трудо-правової суб’єктності), що: 1) здійснюються у сфері праці; 2) окреслені у вигляді норм і закріплені в діючих нормативно-правових актах різних рівнів; 3) є необхідними для гідного існування та розвитку, забезпечення якості життя людини [див., напр.: 5, с. 91]. У межах такої логіки можуть розумітись також і трудові права суддів, які вирізняються з поміж інших характерними для них особливими рисами, з'ясуванню переліку яких вже приділялась увага серед вітчизняних учених [див., напр.: 6, с. 3; 7, с. 134135]. Аналізуючи позиції юристів-трудовиків, а також, приймаючи до уваги значимість роботи судді у правовій державі, доходимо висновку, що особливими рисами трудових прав суддів $\epsilon$ наступні їх характерні ознаки:

1. Трудові права судді складають права, що належать працівникам загалом (основні трудові права), а також трудові права, які належать виключно працівникам із статусом професійного публічного службовця, котрий здійснює правосуддя (обумовлені спеціальним статусом судді). Судді $\epsilon$ «суб'єктами трудового права», котрими науковці називають «фізичних або юридичних осіб, які володіють гарантованими державою та вираженими у правовій формі трудовими правами та виконують трудові обов'язки під час участі у трудових та пов'язаних із ними правовідносинах» [8, c. 82]. Будучи суб'єктами трудового права, судді є працівниками у сенсі ч. 1 ст. 1 Закону України «Про професійні спілки, їх права та гарантії діяльності». При цьому необхідно враховувати наступні закономірності: 1) суддя володіє усіма основними трудовими правами людини, якщо інше прямо не передбачено законами України в силу особливих завдань і функцій, що виконуються суддями; 2) особливі (спеціальні) трудові права судді $€$ аналогією (адаптацією) декотрих загальних прав працівників, що не можуть використовуватись суддями в силу завдань і функцій, які ними виконуються, або ж є правами, що кореспондуються з особливими обов'язками суддів (збалансовують їх дію).

Трудові права, як правова можливість, дозволяють уникнути ситуацій, за яких роботодавцем чи іншими працівниками (колегами) буде принижуватись їх людська гідність, нівелюватиметься свобода, а також інші людські права працівника. Наприклад, суттєве обмеження трудових прав 
і свободи працюючого може уподібнювати його фактичний стан до стану кріпака, а позбавляння таких прав і свобод може створювати ризики для виникнення умов рабства працюючого. Саме тому: 1) виключно набуваючи основні трудові права працездатна людина може повноцінно проживати т. зв. «трудове життя» без шкоди для т. зв. «позатрудового життя», брати участь у суспільних процесах на засадах соціальної справедливості; 2) систематичне та ефективне забезпечення цих основних прав створює реальні умови для того, щоби працівник не лише володів своїми правами, але й міг ними вільно розпоряджатись і користуватись. Іншими словами, неналежне правове регулювання трудових прав працівників, їх забезпечення, а також неефективне забезпечення цих прав є передумовою для появи численних соціальних ризиків для працівників. I, навпаки, - достатнє нормативне закріплення відповідних прав й їх практичне забезпечення є основою для формування належного рівня соціальної безпеки працівників. При цьому, з огляду на специфіку завдань і функцій судді, цілком очевидно, що такий працівник може відчувати належний рівень соціальної безпеки лише за умови, що його основні трудові права також будуть додатково посилені гарантіями мінімізації негативного впливу соціальних ризиків на нього.

2. Трудові права суддів грунтуються на загальній та спеціальній нормативній базі. Правовий статус суддів урегульовується: 1) у трудо-правовій частині: міжнародно-правовими положеннями про права людини; нормами Конституції України та національного законодавства про працю; 2) в адміністративно-правовій частині: міжнародно-правовими положеннями національного законодавства про права публічних службовців загалом і суддів, зокрема; нормами адміністративного законодавства про державних службовців, про судоустрій і статус суддів. Отже, цілком закономірним $€$ те, що трудові права суддів: 1) на відміну від інших працівників, урегульовуються спеціальними нормами, передбаченими для держслужбовців; 2) на відміну від інших професійних публічних службовців регулюються нормами, що поширюють свою дію лише на професійних суддів.

Розуміння нормативної основи трудових прав суддів сприяє тому, що і судді, і суб'єкти, котрі уповноважені забезпечувати ці права та/ або здійснювати їх захист, можуть у належному масштабі розуміти не лише обсяг прав суддів, але й також обсяг кореспондуючих обов'язків зобов'язаних суб'єктів. У цьому сенсі нормативна основа трудових прав суддів постає реальним фундаментом, на якому вибудовуються процеси із забезпечення належного рівня соціальної безпеки суддів у правовій, демократичній і соціальній державі.

3. Трудові права суддів реалізуються виключно у відповідності до вимог ч. 2 ст. 19 Конституції України. Зважаючи на те, що судді за своїм дуалістичним статусом є державними службовцями, на них поширює свою дію конституційний принцип, згідно якого органи державної влади та органи місцевого самоврядування, їх посадові особи зобов'язані діяти лише на підставі, в межах повноважень та у спосіб, що передбачені Конституцією та законами України. Цей принцип законності унеможливлює ситуації, коли суддею, як працівником, будуть реалізовуватись права таким чином, що буде шкодити інтересам людини, громадянина, суспільства та держави, а також авторитету держави, знижуватиме довіру суспільства до судової 
влади. Крім того, враховуючи останні напрацювання у межах питання про реалізацію принципу законності у трудових правовідносинах [див., напр.: 9], опосередкованим чином реалізація трудових прав суддів (також і забезпечення таких прав) усупереч вимогам ч. 2 ст. 19 Конституції України: 1) ставить суддю у становище невизначеності, що негативним чином позначається на його рівні соціальної безпеки; 2) формує умови, за яких виникають соціальні ризики для інших суддів.

4. Трудові права суддів не завжди можуть бути забезпечені та захищені у межах всіх форм захисту трудових прав працівників, однак, додатково забезпечуються і захищаються у межах особливих форм захисту, доступних лише суддям. Зазначена специфіка трудових прав суддів також випливає із особливих, виконуваних ними завдань і функцій, що сукупно вимагають:

1) особливих обмежень суддів не лише в реалізації трудових прав, але й в їх захисті. Наприклад, суддя, на відміну від інших працівників, обмежується в спроможності звернутись до форм колективного захисту його прав, а тому, не може організувати чи приєднатись до страйку. Також суддя не може використовувати переваги звернення за захистом до комісії по трудових спорах, а також в обмеженому вигляді застосовує таку неюрисдикційну форму захисту, як самозахист (у цьому аспекті застосовується така ж логіка, що і відносно інших держслужбовців [див., напр.: 10]);

2) особливих гарантій забезпечення самостійності трудової діяльності суддів та незалежності судової влади. Відповідні гарантії передбачають створення та функціонування особливих способів захисту трудових прав суддів, що частково урівноважують обмеження суддів у використанні окремих загальних форм захисту трудових прав працівників.

Отже, окреслені обмеження можливостей суддів у сфері праці та збалансовані додаткові можливості суддів у цій сфері сприяють уникненню ситуацій, коли судді, намагаючись захистити свої трудові права, створюватимуть загрозу для належного функціонування судової влади, а відтак і для самих себе, послаблюючи закріплені в законодавстві гарантії самостійності трудової діяльності суддів. При цьому, порушення засади самостійності його трудової діяльності $\epsilon$ причиною множини небезпечних соціальних ризиків, з якими може зіштовхнутись суддя у практичній дійсності.

Висновки. Узагальнюючи результати дослідження, доходимо думки, що рівень соціальної безпеки суддів залежить від дійсної якості забезпечення їх трудових прав, що може бути пояснене тим, що ці права: 1) існують задля сталого розвитку людини (задоволення потреб у соціальних благах, що продукуються в сфері праці) та унеможливлення виникнення ситуацій, за яких працівник зазнає приниження його людської гідності, звуження його свободи, а також інших людських прав; 2) регламентуються загальними та спеціальними нормами, що враховують загальні для всіх працівників і особливі для суддів соціальні ризики, 3 метою мінімізацію негативного впливу яких державою й гарантуються відповідні права; 3) здійснюються у відповідності до принципу законності, знижуючи рівень невизначеності як процесу реалізації суддею цих прав, так і процесу забезпечення і захисту цих прав зобов'язаними забезпечувати (захищати) ці права суб'єктами; 4) забезпечуються та захищаються за 
рахунок Державного бюджету України, будучи гарантованими державою (на національному рівні) та міжнародними урядовими організаціями (на міжнародному рівні); 5) захищаються в межах окремих загальних форм захисту трудових прав суддів, а також у рамках спеціально створених для суддів способів захисту вказаних прав.

\section{СПИСОК ВИКОРИСТАНИХ ДЖЕРЕЛ}

1. Шабанов P. I. Правове регулювання праці суддів нормами трудового права. Підприємнищтво, господарство і право. 2020. № 5. С. 112-117. doi:10.32849/2663-5313/2020.5.19.

2. Панченко М. В. Судові органи у правовому забезпеченні гідної праці на державній службі. Підприємнищтво, господарство і право. 2019. № 11. С. 140-144. doi:10.32849/2663-5313/2019.11.22.

3. Коротких А. Ю. Проблеми юридичної відповідальності державних службовців за трудовим законодавством України : дис. ... д-ра юрид. наук : 12.00.05. Київ, 2019. 472 с.

4. Карпушова О. В. Правове регулювання праці суддів в Україні та країнах Європейського Союзу: теорія, практика, проблеми : монографія. Київ : Центр учбової літератури, 2020. 424 с.

5. Вавженчук С. Я. Сутність поняття «конституційні трудові права». Форум права. 2009. № 3. С. 89-93.

6. Штих Т. В. Правовий статус суддів як суб'єктів трудового права України : автореф. дис. ... канд. юрид. наук : 12.00.05. Луганськ, 2010. 19 с.

7. Ярема В. А. Ознаки трудових прав суддів. Наукові дослідження сучасного законодавства України - прогрес юридичної науки XXI cm. : матер. міжнар. наук.-практ. конф. (Київ, 25-26 черв. 2015 р.). Київ : НДІПП, 2015. C. $132-135$.

8. Клемпарський М. М. Сутність, зміст та особливості загального правового статусу суб'єкта трудового права. Вісник Одеського національного університету. Серія: Правознавство. 2011. Т. 16, Вип. 19. С. 75-84.

9. Іншин М. І., Багрій В. А. Проблеми реалізації принципу законності у трудових правовідносинах. Проблеми законності. 2019. Вип. 144. С. 81-92. doi:10.21564/2414-990x.144.154289.

10. Іншин M. I. Індивідуальний захист трудових прав державними службовцями. Вісник Одеського національного університету. Серія : Правознавство. 2011. Т. 16, Вип. 15. С. 135-140.

\section{Inshyn}

\section{ENSURING THE EMPLOYMENT RIGHTS OF JUDGES AS A PREREQUISITE FOR THEIR SOCIAL SECURITY}

The article forms an actual scientific idea about the impact of ensuring the labor rights of judges in Ukraine on the level of their social security. It is determined that the level of social security of judges depends on the quality of ensuring their labor rights, because such rights exist for sustainable human development, that is, there is a satisfaction of the needs for social benefits that are produced in the field of labor. Rights exist to prevent the occurrence of situations in which an employee 
experiences humiliation of his human dignity, restriction of his freedom, as well as other human rights. The rights are regulated by general and special rules, considering the social risks common to all employees and special for judges. Such regulation is carried out to reduce the negative impact on judges. This regulation is subject to the principle of legality. Labor rights are ensured and protected at the expense of the State Budget of Ukraine. They are guaranteed by the State at the national level and by international governmental organizations at the international level. The labor rights of judges can be protected both in the general order, considering certain exceptions, and with the help of special forms of protection that are provided only for judges. The level of implementation and protection of the labor rights of judges determines the level of civilization of society. It is proved that the peculiarities of the labor rights of judges and their impact on the social security of judges require the state to create favorable conditions for their provision. In cases where the State ignores such a duty and the employment rights of a judge are not sufficiently ensured, the State concerned cannot be considered social, legal, and democratic. The lack of guarantees for the implementation of the labor rights of judges, which is currently happening in Ukraine, negatively affects the independence of the courts and the proper administration of justice in the country.

Keywords: judge, judicial and legal reform, labor relations, labor rights, social security. 